\title{
Language Education and Youth Empowerment: A Linguistic Strategy for Achieving Nigeria's Millennium Development Goals
}

\author{
Anthony A. Olaoye \\ Department of English Language and Literature, Nigerian Turkish Nile University, Abuja, Nigeria
}

\begin{abstract}
Language education is being considered in this paper as a veritable weapon or tool for youth empowerment. The author examines the contributions of Applied Linguistics to the realization of the Millennium Development Goals (MDGs). Particular attention is paid to Nigeria's National Policy on Education, specifically theNational Language Policy and its implementation strategies. The essence of this approach is to ascertain whether or not these policies have any sound philosophical orideological basis, and also whether or not there are pragmatic strategies for achieving the goals,especially that of youth empowerment. The paper posits that the education sector of the Nigerian society is supposed to be a very fertile ground for the generation and cultivation of new intellectual ideas, concepts and practices that can be applied to address the MDGs. To support this assertion, the author examines the documents on theNational Economic Empowerment and Development Strategy (NEEDS), and the State Economic Empowerment and Development Strategy (SEEDS). It was found that Education For All (EFA) goals - aspects of MDGs- are laudable but their achievement is fraught with some intractable problems. Crafting philosophically sound policies isone thing but implementing them religiously is a different ball game. The author therefore proposessome linguistic strategies termed "Linguistic Andragogy" as a way out for effective youth empowerment.
\end{abstract}

Index Terms - language education, linguistic andragogy, youth empowerment, millennium development goals, onomastics/onomasiology, ethnography of speaking, acculturation, linguistic right

\section{INTRODUCTION}

Empowerment is defined as the process whereby people are endowed or given the power and the opportunity to improve themselves in order to contribute to positive change (Olaoye, 2005). It can also be defined as a process of challenging the dominant power structures that may inhibit or hinder one's personal growth and advancement in the society, in order to gain recognition, control, and power. Empowerment takes many and varied dimensions, which include activities like individual self-assertion, self-improvement, collective bargaining or resistance, in order to challenge existing power relations. Self-empowerment takes varied forms, such as education for social uplift, apprenticeship for job or occupational advancement, usurpation through domination and force. Our concern is how the youth can be empowered in order to be able to contribute to community and national development. But who are the peopledescribed as the youths? Theyouths are those who fall between the age bracketof the adolescents and the aged, that is from teenageup to the forties.

\section{A. Attributes of the Youth}

What are the attributes or characteristics of the youth? The youths, whether male or female, form the most formidable, energetic work force of any nation, hence they are regarded as the life-wire of the economy of any country. They also form a large percentage of the students in our tertiary institutions. The youths constitute a big percentage of teaching workforce and the National Youth Service Corp membersin Nigeria. The youths serve a nation in many capacities, for instance, as teachers, guidance counsellors, factory hands, farm hands, tradesmen and women, professionals in variousfields, social workers, office workers or civil servants, politicians, spiritual leaders, military men and women, private sector engines of growth, media practitioners and vanguards of democracy, and unfortunately as armed robbers, cultists, prostitutes, drug addicts, examinations malpractice culprits, religious bigots, 419ners, economic saboteurs, and so forth. it is really unfortunate because these negative attributes are the consequences of the many years of neglect of the youths by successive governments who have failed to sufficiently empower the youths.

\section{B. Empowering the Youth through Education}

Education is the most fundamental and important tool for youth empowerment, which in turn is a catalyst for social justice, equity, individual growth and national development. Education is a weapon for the uplift of the under-privileged, the marginalized, the un-informed and the oppressed in the society. The culture of reforminitiated by the previous and present administration is to engender sustainable change in the society. This change is to be engineered through our education institutions. This is one of the Millennium Development Goals that runs through the National Economic 
Empowerment and Development Strategy (NEEDS) at the federal level,and the state Economic Empowerment Strategy (SEEDS) at the state level (NPC 2004). These reforms are to be carried out through education (UNESCO 2005). Different types of education programmes for the empowerment of the youths have been designed. We have citizenship education, human rights education, peace education, vocational or entrepreneurship education, computer education and language education.

The objective of education in general is the improvement of the intellectual capabilities of the beneficiaries or the acquisition of some essential skills, and a further elevation of the persons from the position of low value or status to one of higher value and recognition (Lassa, 1996). The various fields under general education will further empower the youth become well exposed, rational in thought and action, critical, sensible and responsible.

\section{National Policy on Language Education}

Since education is given or delivered through language, either in the Mother Tongue (MT) or in English Language, or whatever, the role of language in youth empowerment cannot be over-emphasized. Language is the vehicle through which knowledge is imparted; and knowledge is power. One of the cardinal points in (NEEDS) is education, and language education is a key tool and a bridge to the future. Mother Tongue education is a weapon for the empowerment of the child and the youth. Through MT the youths are introduced to their culture. It is a mark of identity. Language in general is a tool for national and global integration and sustainable democracy. It is a tool for actualizing human ingenuity and creativity.

Language education is as old as formal (Western) education in Nigeria. The 1926 Colonial Education Ordinance (CLO) can be said to be the first milestone in language education. It was however the 1952 and 1954 primary school syllabus for the Eastern and Western Regions of Nigeria that really emphasized the study of Nigerian Languages. Provisions were then made in the syllabi for Igbo and Efik in the Eastern Region, while Yoruba was for the Western Region, and Hausa for the Northern Region. These syllabi formed the foundation upon which the 1981 and the 1998 revised National Policy on Education was laid.

The multilingual and historical experience of colonialism has had a major impact on language education policy in West Africa, particularly Nigeria. In most part of Africa, a persistent theme of national education meetings has often resulted in the utilization of African (Nigerian) languages as media of instruction in schools. The advantage derivable from this fact is that African Languages and tradition constitute the indispensable foundation of any educational and cultural advancement in Africa.

The principle of Mother Tongue education is closely tied to the education objective of cognitive development, and this is another millennium development goal for the youth. MT education has beenstrongly recommended by UNESCO, to the effect that every effort should be made to provide education in the MT.The role and importance of indigenous languages in Nigeria's education system cannot be over-emphasized. In other climes, children from developed countries explore their own natural environments, and communicate in their native languages, thus acquiring, at a very early stage, self-confidence, resourcefulness, creative reasoning and adaptability skills necessary for further physical, emotional and intellectual development. Teaching both the pupils and the youth three main Nigerian languages will also enable them know their cultures, and to respect other people's ideas and opinions, people's values and beliefs. Since indigenous languages transmit and preserve the people's culture, education given through MT is bound to produce children and youth with moral finesse, a sense of responsibility and the right attitude to life, thus making children and the youths shun ethnocentrism or cultural stereotypes and biases.

\section{LITERATURE REVIEW}

\section{A. Linguistic Andragogy}

Linguistics studies, both theoretical and applied are a good source of youth empowerment. Linguistics studies prepare the youth in the art of communication. Performance in spoken language defines man's personality. Articulate youths always invariably win the hearts and respect of their hearers or listeners. Empowerment through languageeducation promises the youths an escape from both economic poverty and oppression. It promises greater social prestige, job mobility and a better future prospect. These are some of the Millennium Development Goals envisioned by government for the youths.

Empowerment struggles begin at infancy during the child's language acquisition period. The various stages of language acquisition - preverbal babbling stage, holophrastic, telegraphic and the semantic stage prepare the child for adolescence and adulthood. The child's Mother Tongue (MT) is the functional tool for youth empowerment. The MT has both instrumental and integrative functions. It is also used for regulatory purposes; to control other people's behaviour, through warning, persuading, dissuading, commanding, directing, threatening, cajoling, teasing, mocking, praising and reprimanding, These are the illocutionary functions of the MT. It also serves interactional and heuristic purposes. The youths with a good grounding in their MTs are endowed with intellectual, economic and socio-political arsenal of polemic war.

Applied linguistics studies, especially sociolinguistics, psycholinguistics, pragmatics and anthropological linguistics, prepare the youth for future challenges in the society. These studies are capable of acculturating the youths in the art of speaking, especially public elocution skills, such as turn-taking, intercalary expressions, phatic communion and 
illocutionary acts. Language education or Applied Linguistics is useful in preparing the youths in tertiary institutions to understand and master other fields of education. For instance, knowledge of linguistics and the social sciences: philosophy, philology, sociology, psychology, anthropology, geography, history, social studies, government and religious knowledge - the interplay of which results in such fields as philosophical linguistics, sociolinguistics, psycholinguistics, anthropological linguistics, geo-linguistics, helps in exposing the youths to knowledge explosion and new world order. Citizenship education, social valueseducation, peace education, entrepreneurship education, science andtechnological education, can only be taught through language, and they are better done through the MT.

Political sociolinguistics, for instance, prepares the youths for activeparticipation in politics, as they learn the relevant and appropriateregister for politics, religion and social behaviour in their speechcommunity. They learn about linguistic and cultural taboos, such as telling lies, swearing, cursing, rape, greed and squander-mania. For linguisticand social inequality some cultural sanctions are imposed on any breach of language etiquette. Since language can be regarded as the celestialelectricity which illuminates the darkest part of the linguistically blind person, language studies in linguistics could transform the youth from their primordial barbarity or pristine primitiveness torefined men and women. From ontological point of view, the youths get spiritual empowerment through their knowledge of the language ofintercession, praise worship, prayer diction, and the use of evocative epithets. All these language studies are designed to re-brand the youth and prepare them for future task of re-building the nation.

\section{B. Indigenous Languages and Politics}

Nigerian Languages have a lot to contribute to the evolution and success of democratic culture (Emenanjo, 2004). Through a national language and literacy policy which recognizes egalitarian multilingualism, and thefull empowerment of Nigerian languages as vehicles of communication through literacy, Nigerian languages can become veritable instruments for the full empowerment of the Nigerian youths, and this makes them to fully appreciate democracy, its workings, its values and indeed its raison d'etre, as a way of life (Emenanjo, 2004).

The linguistic equivalent of the 1948 Universal Declaration of Human Rights is the 1996 Universal Declaration of Linguistic Rights. These rights, according to Anikweze et al. (2005) are the right:

- to be recognized as a member of a language community

- to use one's language, both in private and in public.

- to the use of one's own name

- to associate with one's language community

- to maintain and develop one's own culture.

- to own their languages and cultures and for these to be taught.

- to have access to cultural services

- to an equitable utilization of one's language and culturein the media.

These rights have conferred on all Nigerian citizens, through theirindigenous languages, the right and opportunity to participate in partypolitics, express thlir feelings and emotions through the media (Ogunranti,2000), and get involved in cultural shows, drama and exhibition of works of arts.

This truism is supported by Njoku (2004) who believes that Nigerian languages are important instruments in the socio-political lives of all Nigerians. It is in recognition of the primacy of indigenous language that the Federal Government recommended in chapter 5, part 1, Article 55 of the 1999 constitution that the business of the National Assembly shall be conducted in English, and in Hausa, Igbo and Yoruba The constitution as well as the NPE are fundamental documents that promote multilingualism Linguistic competence, indeed competence and performance in the indigenous languages can empower the youth to understand the constitution better and thus making the youthsparticipatefully in democratic politics.

\section{Language, Literature and Culture}

Indigenous languages, literature and culture are inseparable as tools for national development The trios are educative and humanistic resources for achieving national development The three are complementary. There is no literature without language. Literature (poetry, prose, drama) depends on words (languages). Language is the vehicle through which records of events are kept, and people's culture transmitted. In literary language, satire is an artistic weapon used in communicating ideas, thoughts and feelings about what is going on in the society. Literature, through language, humanizes, entertains, warns people of dangerous practices, ridicules people, guides administrators with historical facts, and acts as the mirror of the society. Literature criticizes such evils like corruption, injustice, nepotism, bribery, economic and political sabotage, oppression, colonialism, neo-colonialism, dictatorship, power mongering and other anti-social and anti-democratic practices.

The print and electronic media, through sensational and vitriolic language are capable of purging, cleansing or sanitizing the society of itssocio-economic, religious and political filth. Language andliterature empower the youth to imbibe the right values, and to shun anti-social behaviours.

Literature helps in improving the youths' cognitive and language skills, including their personality and the cultivation of aesthetic sense. Literature is akin to history, as it X-rays people's past history. Literature is therefore a tool for social and cultural development. For instance, through folktales, stories, drama and dance, the youths are taught to imbibe 
good behaviour. Through indigenous poetry, human frayed nerves arerelaxed. Through melodic songs and ballads, youths' worries, anxieties are removed or reduced.Through odes and lyrics perturbed minds are soothed. The transmission of cultural values is done through language. The way a person speaks or writes is, to a certain extent, determined by one's cultural experience, which is in turn determined by one's level of education. Language behaviour is governed by societal norms. Any breach of language rules attracts societal sanctions. People's world view is determined by one's language and culture, hence the view proposed by Sapir (1929) and Whorf(1941)known as SapirWhorfian hypothesis of cultural relativism and linguistic determinism. The world is viewed from the perspective of our indigenous languages. What does not exist in one's culture has no name. Language is thus a shaper of ideas. We dissect the world through the instrumentality of our indigenous language. The youths' world view is constructed through language.

Indigenous languages have the capacity to change the society, while environment too is a social force to be reckoned with in language change. Language adaptation brings about language growth and development. Languages have to accommodate new inventions and ideas, through lexical modernization such as lexical coinage and borrowing. New words and expressions have entered into the lexicon of our indigenous languages through linguistic globalization. Man, as a political animal, has to adapt to the changing environment and language change. There is knowledge explosion brought about by the interplay of language and society. The world is fast becoming a global village through mass communication and information technology. The local languages are now being used in the teaching of science and technology including computer science, thus contributing to advancement in science, health, technology and national development. Indigenous language keyboard has been designed to facilitate language learning. The keyboard has such linguistic facilities as tone markers, diacritics,special orthographies, graphetic and graphological cues. All these are aids to faster learning of computer appreciation. The youths get empowered faster through these linguistic facilities.

\section{Ethnography and Semiotics}

A functional inter-relationship among language, culture and communication has been established (Ajah, 1996). He claims that communication process in any society performs three functions:

a. Surveillance of the environment. Communication informs and warns people, it discloses threats and opportunities affecting the values of the community.

b. Correlation of the components of society in making a response to the environment. It prepares people's mind on how to tackle environmental problems

c. Transmission of the social inheritance. Communication - oral and written - is used to transmit, store, preserve and sustain people's culture.

These three functions are carried out through language. Language and culture are identity markers. People cultivate a given language, and also flaunt or showcase their culture in order to show that they are distinct from other races. Dress, cultural marks, national ensigns, coat of arms, signs and symbols, including flags, in Semiotics, communicate something about a people. The ethnography of speaking or of communication differs from one ethnic group to another. Speech norms and the sanctions that go with the breach of speech norms also differ from community to another. A powerful source of linguisticempowerment of the youth is the knowledge of what Hymes (1962) calls ethnography of communication, encapsulated in the acronym SPEAKING.

The communicative competence of the youth is enhanced by their thorough understanding of Hymes' (1962) acronym SPEAKING. S: Setting (spatio-temporal); P: Participants or interlocutors; E: Ends mean objective; A: Act sequence means topic of discourse; K: Key or manner or tone of speech; I: Instrumentality, this means channels of communication (oral or written mode); N: Norms, mean rules governing speech in the speech community; G: Genres mean style used in communication. Speech is rule governed, and itsbreach can bring about war, while its observance brings peace. The youths who are well armed with this linguistic arsenal would be able to participate in intellectual discourse at both national and international for a such as the AU, UNESCO, UNICEF, Commonwealth, NEPAD, and the United Nations' meetings. This is political empowerment, an aspect of MDGs.

Language communicates thoughts, and the thoughts being communicated in language according Ajah (1996) may be aspects of the people's culture. Here lies the functional relationship in language, culture and communication. Language is therefore a perfect instrument of communication of cultural heritage, cultural identity, a weapon of nationalism, a preserver of historical and archaeological discoveries, and the chief tool for human thinking and intellectual empowerment.

\section{Methodology AND DiscuRSIONS}

\section{A. Introduction}

The author studied the Federal Government's NEEDS document and the State Governments' SEED document and analyzed the role which applied linguistics can play.The following issues are discussed: language acculturation, bilingualism and multilingualism, Teachers' Corps, NYSC Scheme, Teachers' registration, onomasiology, and the role of the Humanities Departments in Nigerian Universities.

B. Acculturation as Youth Empowerment Strategy 
The New Encyclopedia Britanica defines acculturation as the process of change in artifacts, customs, and beliefs that result from the contact of societies with different languages and cultural traditions. It is a process of social adaptation of a group of individuals. The Webster New Collegiate Dictionary (Nigerian - Webster 1981) defines it as cultural modification of an individual, or group of people through prolonged and continuous interaction involving inter-cultural exchange and borrowing with a different culture. Acculturation as youth empowerment strategy is a programme of instruction for the study of Nigerian languages as second language (L2). This programme is offered by Colleges of Education and Universities, and it involves only the three major Nigerian languages.

There are three language centers in Nigeria responsible for the language immersion programmes: Kano for Hausa, NINLAN Aba for Igbo, and Oyo for Yoruba. Students who speak these languages asMT do not need acculturation. Acculturation is a practical - oriented programme which started with the implementation of the NPE (Uluocha, 2000). It was designed to promote national integration. The objective of acculturation is to facilitate inter-ethnic understanding and national unity. The acculturees make friends, exchange views, learn the host culture and borrow some aspects of the host cultures. Through interactions they later relate with their colleagues academically, socially, economically, politically and religiously. This promotes bilingualism with all its advantages.

\section{Bilingualism and Multilingualism}

A bilingual/multilingual youth has an advantage over his monolingual counterpart in many respects. The multilingual or polyglot youth is also likely to be multicultural, and this gives him the opportunity of understanding many peoples and their cultures. This facilitates international engagements - travels, bilateral trade, reading of texts in many languages, migration, participation in international politics, conferences and seminars. Job opportunities are legion. Multilingualism removes ethnocentrism and opens the gate to the innermost recesses of mankind, and makes possible easy access to the cultures of the world. Bilingualism and multilingualism therefore can empower the youth in no small measure.

\section{Teachers' Corps}

For the youths who are out of school and who had no training in language studies or Linguistics ,the Federal Government should establish language learning programmes in both the Teachers' Corps (a two-year capacity- building internship) and the NYSC scheme. This will afford the teacher-interns and the Youth Corp Members the opportunity to become bilingual or multilingual, and hence become more empowered. A form of language immersion programme can be organized to achieve this goal. The Teachers Registration Council (TRC) of Nigeria also has a role to play. Teachers' capacity building programmes should include the teaching andlearning of Nigerian languages.

\section{E. Onomastics}

Naming, otherwise known as Onomastics (Emenanjo 2002) or Onomasiology (Olaoye, 2007), is a tradition and a cross-cultural practice in the ethnology of mankind. Names communicate - they tell people about the origin of the namees and the namers; they provide evidence about language change, either diachronic or synchronic; they also provide information on the socio-economic and religious background of the people. Since names are words (language), and they reflect the thoughts (culture) of a people, names are a veritable weapon in the hands of cultural workers, as names can be used to trace a lost race, identify tribal allies and enemies, control human excesses, and to bring orderliness into the society. The study of Onomastics is another strategy for youth empowerment. Names, (words in different languages and cultures) whether endogenic or exogenic, contribute immensely to the teaching of geolinguistics or linguistic geography, anthropology, sociolinguistics and ethnology.

\section{F. Humanities Departments}

The challenges for the humanities departments in the Nigerian Universities are although daunting but not insurmountable. The department of Linguistics and African Languages, University of Abuja, is making giant strides in running linguistics courses that are capable of providing students with a good language background in English, Arabic and Nigerian languages, with a working knowledge of French and Spanish. The objectives are to equip (i.e. empower) the students (most of who are youths) with a good knowledge of the main principles of current linguistics theories and practices, to train them to be able to apply the knowledge and skills acquired to language-related tasks and problems, particularly in their own environment, and to prepare them for further studies in the discipline and relevant careers in teaching, administration, the media and social engineering. The department, through teaching, research and community services in linguistics and language-related areas, has been contributing her quota toward the realization of Nigeria's MDGs.

\section{CONCLUSION}

The author concludes that, based on the valued and cherished language education programmes of tertiary institutions in Nigeria, Language Education, using linguistic strategies, as a veritable tool for youth empowerment, is capable of achieving Nigeria's millennium development goals. It was found that the Nigerian Education Policy, particularly the National Language Policy, is a very good document which is capable of empowering the youth if well implemented. Education For All (EFA) goals can be achieved if linguistic andragogy is religiously pursued. Education which prepares 
the youth to take up life challenges and which provides opportunities is a veritable tool for achieving social security for the youth. Linguistic andragogy is a humanistic education system which empowers through civic and political reorientation, language acculturation, egalitarian multilingualism, social and moral rearmament ,communicative competence and ITC skills.Empowerment through language education ensures that the youth escapes from intellectual and economic poverty and oppression.Linguistic andragogy is therefore capable of rebranding the youth thus preparing them for the future task of rebuilding the nation, and achieving some of the millennium development goals.

\section{REFERENCES}

[1] Ajah, G.O. (1996). Language culture and communication. A functional inter-relation Approach. Nigeria Research In Education. F.C.E. Eha-Amufu, Vol. VIII.

[2] Anikweze, Charles M. (2005). Peace, human rights and global citizenship education: the mission of PETADISTS Community Organization. Unpublished Paper presented at the Culture of Reform Workshop, FCE Okene, Nigeria.

[3] Emenanjo, Nolue. (2002). How many Nigerian Languages are there? Issues on the definition and identification of languages. Development of the Minority Languages in Nigeria .ANLAT Journal. Aba, Abia State.

[4] Emenanjo, Nolue. (2004). Nigerian languages and the democratic experience. In: Nigerian languages and the Democratic Experience. Proceedings of the $9^{\text {th }}$ annual conference of ANLAT, NINLAN Aba, Nigeria.

[5] Hymes, Dell. (1962). The ethnography of speaking. In Fishman, J.A. (ed) (1968). Readings in the Sociology of Language. The Hague: Mouton.

[6] Lassa, Peter N. (1996). Teacher Education in the $21^{\text {st }}$ Century.The Voice of Prof. P.N. Lassa. Anikweze, C.M. (ed).

[7] National Policy on Education. (1998). Federal Ministry of Education, Nigeria.

[8] Njoku, T.U. (2004). Nigerian languages and the democratic experience. In Nigerian_Languages And The Democratic Experience, Proceedings of ANLAT. NINLAN Aba, Nigeria.

[9] Ogunranti, J.I. (2000). The role of mother tongue as a medium of instruction in the year 2000 and beyond. In: Language, Literature and Linguistics in the $21^{\text {st }}$ Century. Kaduna: NCCE Publication.

[10] Olaoye, A.A. (2005). Promoting empowerment through language studies in the $21^{\text {st }}$ century. An unpublished keynote address presented at the $5^{\text {th }}$ National conference, School of languages, Federal College of Education, Osiele, Abeokuta, Nigeria.

[11] Olaoye, A.A. (2007). Onomasiology: A sociolinguistic analysis of naming tradition among some tribes in Nigeria. An unpublished paper presented at the $21^{\text {st }}$ Linguistic Association of Nigeria (LAN) conference, University of Uyo, Uyo, Nigeria.

[12] Olaoye, A.A. (2008). Language education as a weapon for youth empowerment: $a$ linguistic strategy for achieving aspects of MDGs.Paper presented at the University of Abuja International conference.

[13] Sapir, Edward. (1929). Language. New York: Harcourt, Brace.

[14] UNESCO Abuja. (2005). UNESCO Abuja Activity Profile, Abuja.

[15] Whorf, B.F. (1941).Cultural relativity and linguistic determinism. In: Fishman, J.A.(1971). Advances in the Sociology of Language. The Hague: Mouton

[16] Uluocha, V.C. (2000). The role of Nigerian language acculturation. In: Language, Literature and Linguistics in the $21^{\text {st }}$ Century. Kaduna: NCCE.

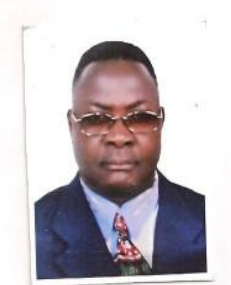

Anthony A. Olaoye was born at Okerimi-Oro, in Irepudun Local Government Area of Kwara State, Nigeria, on the 2nd April, 1949. The author has B.A. (Ed) English/Education, Ahmadu Bello University, Zaria, Nigeria, 1978; M.Ed Curriculum and Instruction, Bayero University, Kano, Nigeria, 1982; M.A. English Language, Bayero University, Kano, Nigeria, 1986; Ph.D, English Language (Sociolinguistics) Ahmadu Bello University, Zaria, Nigeria, 1992.

The author's major field is Applied Linguistics. He has taught English Language and Methodology in a College of Education, and has worked in six different universities in Nigeria, where he taught English Language and Applied Linguistics as a Senior Lecturer. He later rose to the position of an Associate Professor of Applied Linguistics in Kwara State University Malete, Ilorin, Nigeria. He is currently a retired, contract lecturer in the Department of Linguistics and African Languages, University of Abuja, Nigeria, and an Assoc.Prof. in Nigerian Turkish Nile University,Abuja. He has 50 publications, with four books:1. Introduction to Sociolinguistics, 2002;2.Aspects of Applied Linguistics, 2008; 3.Linguistics in Language Education, 2009 and 4.General Studies English: A Practical GuideFor Tertiary Institutions ,2009. His previous and current research interest is in Ethnography of Communication and Language Documentation.

The author's title is Dr. Olaoye, Associate Professor of Applied Linguistics. He is a member of ten Professional Associations some of which are listed below:

- West African Linguistic Congress (WALC)

- Linguistic Association of Nigeria (LAN)

- Association of Nigerian Language Teachers (ANLAT)

- Nigerian Institute of Management (NIM)

- Curriculum Organization of Nigeria (CON)

- Nigerian English Studies Association (NESA)

- Reading Association of Nigeria (RAN)

$\mathrm{He}$ is an awardee of the British Council/Cambridge Summer School Scholarship for Post-Doctoral Language Education Short Course, Homerton College, Cambridge, 1993. He is also a commissioned Language Education Consultant to the National Commission for Colleges of Education (NCCE), National Teachers Institute, Kaduna, and the National Institute for Cultural Orientation (NICO), in Nigeria. 